\title{
Measuring the Mediating Effect of Utilitarian Motive in the Relationship of Product Quality, Product Price with Consumer Purchase Intention
}

\author{
Pratibha Rai, Om Jee Gupta
}

\begin{abstract}
Retail business has always been an attractive business for marketers. In recent years, many research works were being carried out in the retail industry. Most of this research work was being carried out in the developed cities of India but none of the researchers has focused on smaller states or new cities of India. This research work was undertaken in the state of Chhattisgarh (Raipur, Bilaspur and Durg). The researcher has used one dependent variable (consumer purchase intention), three independent variables (product quality, product price and utilitarian motive, and one mediating variable (utilitarian motive). The researcher has used descriptive research design to undertake this work. Convenience sampling method was chosen to collect the primary data for the study. The researcher has collected data from 470 respondents, whereas 153 responses were found to be unsuitable for the study. They were found to be unengaged responses, where respondents have ticked on the answers without reading the questions. After eliminating these questionnaires, the researcher is left with 317 responses. Then the researcher has used confirmatory factor analysis (CFA) to check the validity and reliability of the constructs. Thereafter, the researcher has used structural equation modeling to test the hypothesis.
\end{abstract}

The finding of the study revealed that utilitarian motive significantly mediates the relationship of product quality with consumer purchase intention and product price with consumer purchase intention. At last, the researcher has drawn a managerial implication from this study and has also suggested future areas of researches for the upcoming scholars.

Keywords: Consumer Purchase Intention, Product Quality, Product Price, Organized Retail, Utilitarian Motive, Indian Retail Market.

\section{INTRODUCTION}

Retail segment has always been an important and lucrative business for the marketers. There are many reasons because of which this segment has gained popularity among a large number of marketers. India's organized retail market is about to achieve US\$ 1.1 trillion by the year 2020. This sector is evident with a large number of investments from the Indian market as well as from foreign soil. This sector promises the investors, a large amount of profit with a limited amount of investment. The Government of India has undertaken many

Revised Manuscript Received on September 22, 2019.

Dr. PratibhaRai, Assistant Professor, PSIT College of Higher Education, Kanpur, Uttar Pradesh 209305

Om Jee Gupta, Assistant Professor, PSIT College of Higher Education, Kanpur, Uttar Pradesh 209305 steps to advance the organized retail industry. In the same line, the Government of India has permitted 100 per cent FDI investment in a retail goods and services industry. Many large Indian firms have started to invest or have already invested in the organized retail industry. This particular industry is expanding in a much faster way. Apart from the given benefit to the marketers, it provides several options to the consumers at a reasonable price. Consumers can compare various products offered by many companies at the same platform. Moreover, this industry provides a large number of employments to the masses. Therefore, this industry has been beneficial at all levels.

Previous research work revealed the quality of the product and price of the products has always been the point of concern for the consumers. Every time, when consumers walk into any mall, they usually concerned about the quality of the product and price of the product. At the same time, utilitarian motive also plays an important role in shaping the mind of the consumers. Understanding consumer purchase intention has always been a point of attraction for marketers and researchers.

Hence, this research work was endeavored to understand the impact of product quality, product price and utilitarian motive on consumer purchase intention. It also measures the mediating effect of utilitarian motive in the relationship between product price and consumer purchase intention.

\section{1.1 THEORETICAL FRAMEWORK AND HYPOTHESES:}

\section{A. Product Quality:}

The quality of any product is assessed by consumers, in terms of its superiority and as a better alternative compared to any other available product or services (Keller, 2008). Consumers always assess the quality of the product to other available alternative products. The quality of products does not be assessed physically but it is intangible. At the same time, it is being measured on various important dimensions i.e. brand, performance, and reliability etc. The quality of the product also helps marketers to create an edge over and above to their competitors (Zeeshan, 2013). The quality of the product has widely been considered as an important determinant of assessing the purchase intention of consumers. The studies have 
concluded that if the product's quality is good then consumers will be lean towards purchasing that product (Chi et al., 2008). As we improve the quality of the product, it leads to a higher probability of consumers to purchase that particular product (Tsiotsou, 2005, 2006). Based on these studies, we could say that product quality influences the purchase intention of consumers.

Therefore, we hypothesize:

H1: There is a positive and significant relationship between product quality and consumer purchase intention.

\section{B. 1.2 Product Price}

Price is called that amount of money that we exchange for the product or services that we purchase (Kotler and Armstrong, 2010). Studies have shown that price is the most important factor in determining brand loyalty, and it also subsequently influences consumer purchase intention (Khraim, 2011). It is also being argued that consumer's perception towards price fairness, has an important role in shaping the consumer's decision-making process (Lee et al., 2010). Based on the above studies, we could say that product price significantly influences the purchase intention of consumers.

Therefore, we hypothesize:

H2: There is a positive and significant relationship between product price and consumer purchase intention.

\section{Utilitarian Motive:}

Shopping motives of consumers push the consumers towards the market place to meet their desired need and ultimately satisfy those needs(Jin \& Kim, 2003). The same thing was being propagated by Soloman, motivation leads people to act in a specific manner. It is also being stated that when any need comes in the mind then consumers wish to fulfill that need. The utilitarian motive is cognitive, task-oriented and non-emotional characteristics (Babin et al., 1994; Yavas\&Babakus, 2009). Consumers have various kinds of utilitarian motive like a good price, convenience, and are interested in understanding the product, information about the market. Keeping all the above facts in mind, we can say that utilitarian motive does influence the consumer purchase intention.

Here it is also important to understand that utilitarian motive also has a significant role to play in the relationship between product quality and consumer purchase intention (Sarwar, Azam, Haque, Sleman, \&Nikhashemi, 2013). Although we do understand that product quality impacts consumer purchase intention, if the utilitarian motive is not being fulfilled then consumer may not prefer that particular product irrespective of its good quality. Likewise, if we talk about the product price, it also influences the consumer purchase intention (Engardio, Roberts, \&Bremner, 2004), but it is observed that if the utilitarian motive of the consumer is not met, then lower or higher price of the product is just irrelevant for the consumers. Therefore, in this study, the researcher has empirically examined the mediating effect of utilitarian motive in the relationship of product quality and consumer purchase intention; the researcher also examines the mediating effect of utilitarian motive in the relationship of product price and consumer purchase intention.

Therefore, we hypothesize:

H3: There is a positive and significant relationship between utilitarian motive and consumer purchase intention.

H4: Utilitarian motive mediates the relationship between product price and consumer purchase intention.

H5: Utilitarian motive mediates the relationship between product quality and consumer purchase intention.

\section{Consumer Purchase Intention:}

Consumer purchase intention is comprised of various levels of decision making. It's a complex, tedious, and cumbersome process to understand. It is being considered as the understanding of the consumer's intention to purchase a particular product. Consumer purchase intention has always been considered as an important variable in marketing to understand. It is being considered as an important decision making of the consumer to purchase a particular type of product or services or any specific brand (Shah et al., 2012).

Kotler\& Armstrong (2010) stated that it is a condition or a certain circumstance, where consumers lean towards purchasing a certain type of services or products. Consumer purchase intention widely being used to forecast the buying process of consumers (Ghosh, 1990). It is also being argued that consumer purchase intention does change with respect to perceived quality and perceived price. Consumer's utilitarian motive also influences consumer purchase intention. Utilitarian motives are being considered as benefits that consumer attaches with the product while shopping (Babin, Darden, \& Griffin, 1994).

\section{RESEARCH METHODOLOGY}

\section{E. Statement of Problem:}

Shopping malls are a reality today in the retail business. Mostly in urban places, shopping malls have become important destinations for shopping. People use to prefer shopping malls than purchasing products from any local store. These days marketing activities are travelling beyond the limits of just selling the products itself. Marketers used to assess the behavior of consumers through their purchase intentions. 
Therefore, understanding the purchase intention of consumers attract a huge amount of importance from the marketers. Consumer purchase intention depends on various independent variables i.e. product quality, product price, utilitarian motive etc.

On various occasions, it is observed that in spite of the quality of the products being adequate, consumers do not purchase products. On other instances, it is also found that the price of the products does influences the consumer purchase intention, if the price of the product is lower, even then consumers refrain in purchasing those products.

Hence, it is observed that in spite of having an adequate quality of products and reasonable price of the products, why at times consumers do not purchase products from shopping malls. This instance simply talks about a mismatch between an expected and reality. Therefore, a consequence like this urges research work to be undertaken to understand the reality of this situation.

\section{F. Research Design}

A descriptive approach has been adopted in the study.A non-experimental, cross-sectional survey was conducted to collect data. For testing the proposed hypothesis a self-administered, structured questionnaire was executed to collect the data from the various shopping malls present in three cities of Chhattisgarh (Raipur, Bilaspur and Durg). The statements of the questionnaire were drawn from previous literature; Reliability and validity of the research instrument were checked by Confirmatory factor analysis (CFA).

\section{G. Questionnaire Design:}

A structured questionnaire consisting of statements related to constructs prepared for the collection of data. Questionnaire divided into five parts. The first part included the information about personal characteristics of the sample, in the second part there were 5 statements related to product quality, third part included 4 statements related to product price, fourth part comprised 4 statement related to utilitarian motive of shoppers and fifth part included 4 statements related to consumer purchase intention. All the statements were measured by using a five-point Likert scale (where $5=$ strongly agree to $1=$ strongly disagree)

\section{H. Sampling Procedure:}

All the young shoppers above 18 years of age, who visit malls, make population for the study. In this research work, identification of sampling frame was quite difficult, as no individual can create a list of all the shoppers, so in a broader term, shopping malls considered as a sampling frame for the study, and the researcher has resorted to conducting this study using non-probability sampling technique. collected by the mall intercept survey method. The shoppers were contacted at the exit of the store and requested to fill the Convenience sampling was used in the study and data were

questionnaire. The different period and days were used to reduce sampling bias.

\section{Data Collection:}

This research work was undertaken in the state of Chhattisgarh (Raipur, Bilaspur and Durg). Before turned to the final data collection, the researcher has used pilot testing method to check the reliability and validity. The content validity was checked and found suitable to conduct this study. The researcher has selected 30 samples for pilot testing. Finally, the researcher has collected data from 470 respondents, whereas 153 responses were found to be unsuitable for the study. They were found to be unengaged responses, where respondents have ticked on the answers without reading the questions. After eliminating these questionnaires, the researcher is left with 317 responses. Final collected data were adequately sorted; edited, tabulated and the proper code has been assigned to each statement of the questionnaire. For establishing the relationship between variables sophisticated structure equations modeling (SEM) has been used

\section{DATA ANALYSIS:}

\section{J. Description of Data:}

Table 1 demonstrates the description of the sample used in the study. Total 317 samples were collected for the final study, out of which $45.5 \%$ were female and $54.5 \%$ were male which indicates the majority of male respondents in the sample. Majority of respondents $(67.39 \%)$ belonged to middle adult age group (31-50) while $32.61 \%$ belongs to the age group of 18-30. Majority of the respondents were Graduates $56.46 \%$ and $43.54 \%$ were in the group of PG and above.

Table 1: Demographic Characteristics

\begin{tabular}{|c|c|c|}
\hline Variables & Categories & Response (\%) \\
\hline \multirow{2}{*}{ Gender } & Male & 54.5 \\
\cline { 2 - 3 } & Female & 45.5 \\
\hline \multirow{2}{*}{ Age } & $18-30$ & 32.61 \\
\cline { 2 - 3 } & $31-50$ & 67.39 \\
\hline \multirow{2}{*}{ Education } & Graduate & 56.46 \\
\cline { 2 - 3 } & PG and above & 43.54 \\
\hline
\end{tabular}

\section{MEASUREMENT MODEL}

For checking the relationship of variables in a measurement model and validity and reliability of used instrument confirmatory factor analysis (CFA) has been used in the study, 

Consumer Purchase Intention

because before proceeding towards structural model it is mandatory to check the reliability and validity of scale (Fornell and Larcker, 1981; Ifinedo, 2006).

The measurement model of study (Figure 1) is portrayingthe loadings of observed variables (items) to their corresponding constructs (latent variables) and the relationship between latent variables.

The model comprises of four constructs i.e. quality (5 items), price (4 items), utilitarian motive (4 items) and purchase intention (4 items), so a total seventeen items could be seen in the model.

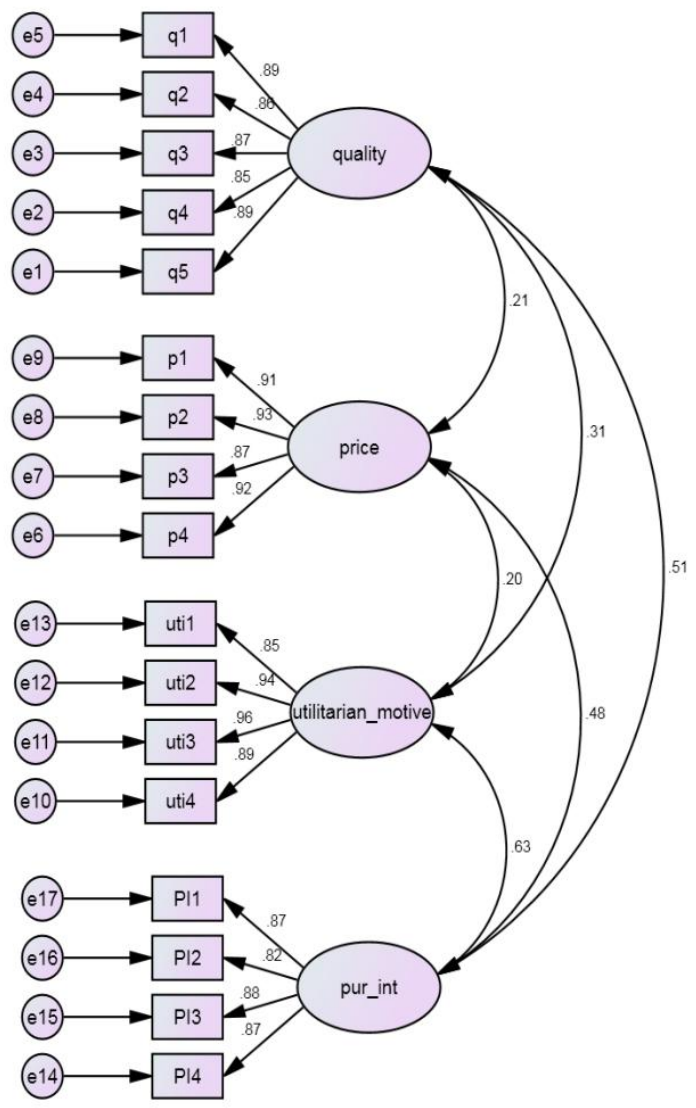

Figure 1: Measurement Model

Table 2 demonstrates standardized regression weight (factor loadings) of scale items to their respective constructs. It could be seen here that factor loading of each item to their respective construct is above 0.82 (range from 0.82 to 0.94 ). According to convergent validity principles, all the factors loading should be significantly contributing to their respective construct (Anderson \&Gerbing, 1988; Bollen, 1989), and this could also be seen here that all the factors loadings are significantly contributing to their construct.

Table 2: Factor Loadings and Other Measures

\begin{tabular}{|c|c|c|c|c|c|c|c|}
\hline $\begin{array}{c}\text { Constr } \\
\text { uct }\end{array}$ & $\begin{array}{c}\text { Ite } \\
\text { ms }\end{array}$ & $\begin{array}{c}\text { Standard } \\
\text { factor } \\
\text { loading }\end{array}$ & (CR) & $\begin{array}{c}\text { (AV } \\
\text { E) }\end{array}$ & $\begin{array}{c}\text { (AS } \\
\text { V) }\end{array}$ & $\begin{array}{c}\text { (MS } \\
\text { V) }\end{array}$ & $\begin{array}{c}\text { Cronb } \\
\text { ach } \\
\text { alpha }\end{array}$ \\
\hline \multirow{5}{*}{ Quality } & 1 & 0.887 & 0.941 & 0.76 & 0.13 & 0.26 & .940 \\
& 2 & 0.859 & & 0 & 4 & 1 & \\
\cline { 2 - 5 } & 3 & 0.874 & & & & & \\
\cline { 2 - 5 } & 4 & 0.850 & & & & & \\
\hline
\end{tabular}

$A V E=$ Average variance extracted $; M S V=$ Maximum shared variance; $C R=$ Composite reliability;

Source: created by Author

Table 2also contains the value of average variance extracted (AVE), composite reliability (CR), average shared variance (ASV) and maximum shared variance (MSV). Conventionally, accepted value of AVE IS .50 and here in this study value of AVE of every single construct is greater than .50 , indicating that all the items of respective constructs are converging appropriately. (Hair et al., 2010; Fornell\&Larcker, 1981).

Acceptable value of composite reliability is 0.70 (Bagozzi\& Yi, 1988; Fornell\&Larcker, 1981) and here, CR Value of each construct is ranging from .920 to .952 , indicating criteria of composite reliability has been met. In addition to that, internal consistency of scale has been measured by Cronbachalpha, and the value of alpha is above .70, indicating scale is internally consistent.

If the value of CR is greater than AVE, It depicts that all the items are converging to their respective construct, which establishes the convergent validity (Fornell\&Larcker, 1981; Hair et al., 2010), and in this study dataset meets the criteria where $\mathrm{CR}$ of each construct is greater than their AVE value. i.e. $($ Quality $=0.941>0.760)$; $($ Price $=0.949>0.824)$; $($ Utilitarian motive $=0.952>0.832)$; $($ Purchase intention $=$ $0.920>0.743$ ) (Table 2)

Discriminant validity exhibits the distinction of one construct with other constructs (Hair et al., 2010). Discriminant validity can be established by comparing the AVE value of each single construct with the ASV value and MSV value of other respective constructs (Fornell\&Larcker, 1981). In Table 2, it could be clearly seen that AVE value of each construct is greater than ASV value and MSV value, indicating discriminant validity in the study. For Quality (AVE= 0.941) $>(\mathrm{ASV}=0.134)$ and $(\mathrm{MSV}=0.261)$; Price $(\mathrm{AVE}=0.949)>\quad(\mathrm{ASV}=0.106)$ and $(\mathrm{MSV}=0.234)$; Utilitarian motive $(\mathrm{AVE}=0.832)>(\mathrm{ASV}=$ $0.180)$ and $(\mathrm{MSV}=0.402)$; Purchase intention $(\mathrm{AVE}=0.743)>\quad(\mathrm{ASV}=0.299)$ and $(\mathrm{MSV}=0.402)$. 
In this study, the model fit indices i.e. Tucker-Lewis index (TLI), Goodness of fit index (GFI), comparative fit index (CFI), normed fit index (NFI), (Goodness of fit) and root mean square of error approximation (RMSEA) (Badness of fit) were selected to evaluate model fitness (Hair et al., 2010).

The proposed model fits with the collected data used to be measured by CMIN/DF the standard criteria of CMIN/DF<

3. The value of TLI, GFI, NFI, CFI, should be more than 0.90 and RMSEA $<0.08$ (Gefen\& Straub, 2000).

The final CFA model or measurement model presented a good fit with the data itself $(\mathrm{CMIN} / \mathrm{DF}=2.925, \mathrm{CFI}=0$. $0.960, \mathrm{TLI}=0.952, \mathrm{NFI}=0.940, \mathrm{RMSEA}=0.078$, which was reported to be significant (Bagozzi\& Yi, 1988;

Bentler\&Bonett, 1980).

Table 3: Model Fitness

\begin{tabular}{|c|c|c|c|c|c|}
\hline CMIN/DF & CFI & IFI & TLI & NFI & RMSEA \\
\hline 2.925 & 0.96 & 0.96 & 0.952 & 0.94 & 0.078 \\
\hline
\end{tabular}

Table 3portrays that the measurement model stands good fit with the data; therefore we could proceed with testing other hypotheses in the structural model through SEM.

\section{V.STRUCTURAL MODEL}

In structural modeling SRW (standardized regression weight), Critical ratio, standard error and hypothesis results have been presented in table 4 and figure 2. Table 4 also showing the strength and direction of the relationships of constructs.

Figure 2 and Table 4 demonstrate the unmediated structural model. The result of this model shows the $\beta$ value, $t$-value and significance of all the path coefficients. The researcher has found that product quality $(\beta=0.295$; $\mathrm{t}$-statistics $=6.548$; $\mathrm{p}<0.001)$, product price $(\beta=0.327 ; \mathrm{t}$-statistics $=7.521$; $p<0.001)$, utilitarian motive $(\beta=0.475$; t-statistics $=10.139$; $\mathrm{p}<0.001)$ significantly and positively affecting consumer purchase intention.

Table 4: Results of Hypothesis Testing

\begin{tabular}{|c|c|c|c|}
\hline $\begin{array}{c}\text { Hypothesis } \\
\text { Relationship }\end{array}$ & SRW & $\begin{array}{c}\text { Critical } \\
\text { ratio (t) }\end{array}$ & Sig (p) \\
\hline $\begin{array}{c}\text { Quality-Purchase } \\
\text { intention }\end{array}$ & 0.295 & 6.548 & $<0.001$ \\
\hline $\begin{array}{c}\text { Price-Purchase } \\
\text { intention }\end{array}$ & 0.327 & 7.521 & $<0.001$ \\
\hline $\begin{array}{c}\text { Utilitarian motive- } \\
\text { Purchase intention }\end{array}$ & 0.475 & 10.139 & $<0.001$ \\
\hline
\end{tabular}

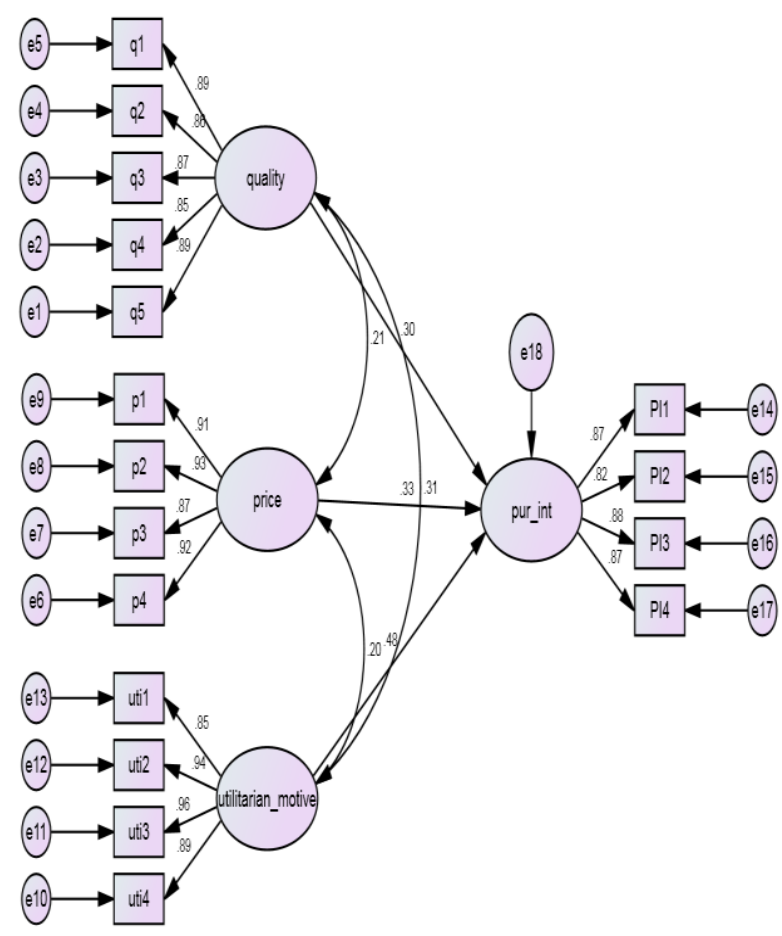

Figure 2: Unmediated structural model

K. Mediation Analysis:

1. Utilitarian motive mediate the relationship between product quality and purchase intention:

Figure 3 shows the mediated structural model. The result of this model shows important findings. The direct path between product quality and consumer purchase intention in the presence of mediator i.e. utilitarian motive, we found that the direct path was between product quality and consumer purchase intention was $(\beta=0.308 ; \quad t$-statistics $=6.727$; $\mathrm{p}<0.001)$ whereas the indirect effect between product quality and consumer purchase intention through mediator (utilitarian motive) was found significant $(\beta=0.139$; $\mathrm{p}<0.001)$. Here it is important to note that utilitarian motive significantly mediates the relationship between product quality and consumer purchase intention. At the same time, both direct and indirect path was found significant, hence we could conclude that utilitarian motive partially mediates the relationship between product quality and consumer purchase intention. 


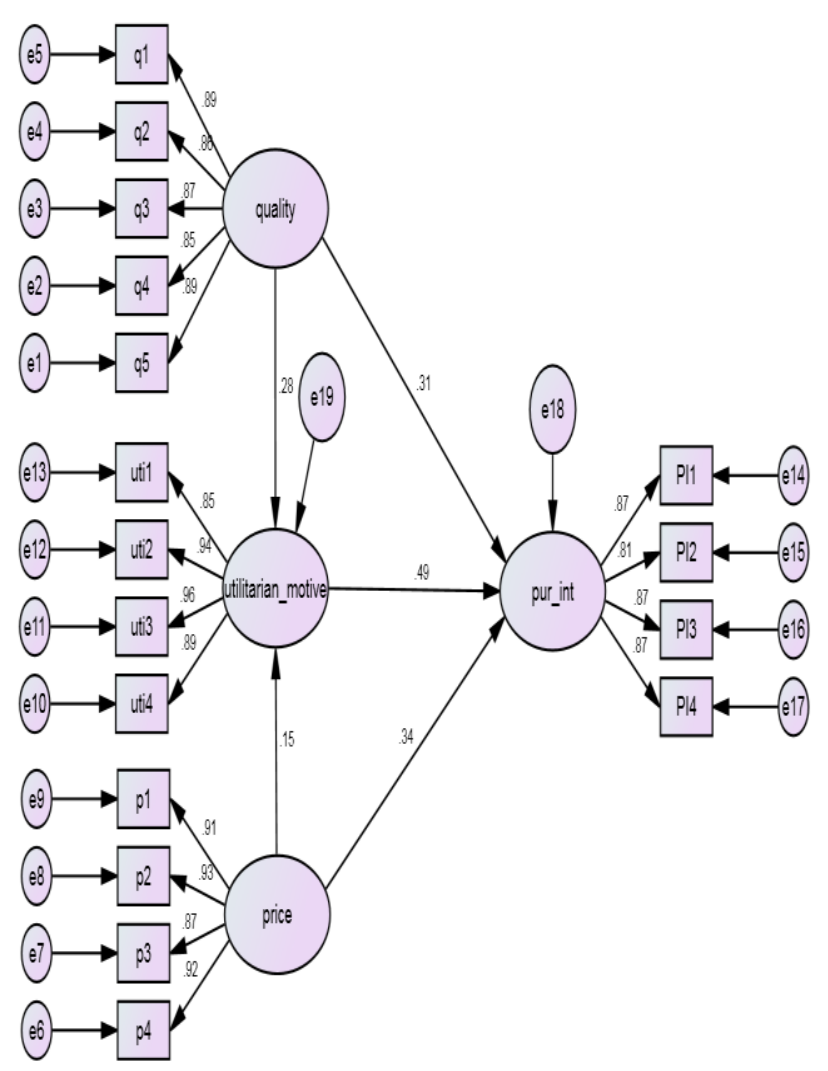

Figure 3: Mediated structural model

\section{Utilitarian motive mediate the relationship between product price and purchase intention}

Figure 3 shows the mediated structural model. The result of this model shows important findings. The direct path between product price and consumer purchase intention in the presence of mediator i.e. utilitarian motive, we found that the direct path was between product quality and consumer purchase intention was $(\beta=0.342 ; \quad t$-statistics $=2.637$; $p<0.001)$ whereas the indirect effect between product price and consumer purchase intention through mediator (utilitarian motive) was found significant $(\beta=0.072$; $p<0.023)$. Here it is important to note that utilitarian motive significantly mediates the relationship between product price and consumer purchase intention. At the same time, both direct and indirect path was found significant, hence we could conclude that utilitarian motive partially mediates the relationship between product price and consumer purchase intention.

\section{MANAGERIAL IMPLICATION}

The researcher has drawn significant implications out of this study. The study gives an implication for the marketers and academicians. The study revealed that the quality of the product has a positive and significant relationship with consumer purchase intention in the context of shopping malls. This particular finding depicts that, in spite of several promotional tools, aesthetic store atmosphere etc. product quality remained an important determinant to frame consumer's intention to purchase a particular product. This study is opposite to a popular belief that says "Anything could be sold out if proper promotional tools and ambience of the shopping malls are maintained". Here marketers are advised that while keeping all the promotional tools and ambience at the place, they need to maintain their product's quality because the finding of this study empirically confirms that quality of the product is still prevalent in shaping the mind of the consumers for purchasing a particular product. Marketers could also understand that the quality of the product is still a very core part of consumer understanding and that has to be taken care of. This finding also adds to the existing body of knowledge, because no study has empirically tested this concept in the state of Chhattisgarh, which is known to be a developing state. This particular model could also be used in other developing states by the researchers.

Price of the product has always been an important determinant of consumer purchase intention. In general, a popular belief is that when we talk about shopping malls; people generally least bother about the price. But this study has put forth a shred of empirically glaring evidence that the price of the product does matter even when the consumers are purchasing products in the shopping malls. It is also advised to the marketers that they should not play a free hand while dealing or fixing the price of the product because the price has been considered by the consumers as an important determinant in shaping their mind to purchase products in shopping malls. This study also makes a significant academic contribution because no previous studies were conducted in the context of shopping malls. The researcher is advised to undertake a similar kind of study in other developing states so that we could witness some more glaring evidence coming from other parts of the country.

The study also reveals that utilitarian motive positively and significantly contributes to framing the consumer intention to purchase products in shopping malls. Here marketers are advised to make sure that all the possible utilitarian motive of consumers should be addressed appropriately. The study depicts that utilitarian motive is very important determinant and significantly contributes to shaping the thought of consumers. It is also important to understand that consumers do have different motives when they come to purchase products from shopping malls. These different motives need to be addressed differently by marketers. In general shopping malls have a large number of consumers having different needs. One set of consumers used to go to malls just to purchase different products of different quality and price. Another set of the consumer goes to malls not to purchase but just to see the products and but may end up purchasing the product itself. The challenge

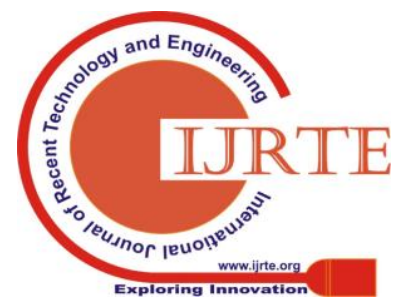


before the marketer is to convert this later set of consumers (window shopper) into a potential consumer. This study tells us that this could only be possible if the marketer would take care of the utilitarian needs of the consumers and assure to fulfill the same positively. Hence the finding of this study suggests that marketers are required to take utmost care in satisfying the utilitarian motive of consumers, this would help the marketer to convert more window shopper visiting shopping malls into the consumers who purchase products from shopping malls.

The study also leaves another important implication for marketers. The study revealed that utilitarian motive mediates the relationship between product price and consumer purchase intention. This simply suggests the marketers even in the case where the price of the product is higher; if the utilitarian motive is satisfied then the higher price of the products carries least bother in the mind of the consumers. In other words, consumers are ready to pay a higher price for the particular products if their utilitarian motive is stood satisfied. The study also leaves an important implication for the academicians as no prior study has tested the mediation effect of utilitarian motive in the relationship between product price and consumer purchase intention. More glaring evidence could be gathered if researchers could conduct a similar kind of study in different contexts.

The study also talks about the mediation effect of utilitarian motive in the relationship between product quality and consumer purchase intention. It is evident that the quality of the product really matters for the consumers and subsequently affects consumer purchase intention. Here the marketers are advised to make sure that the utilitarian motive of consumers has to be met by the marketer's offer. The utilitarian motive is partially mediating the relationship between product quality and consumer purchase intention. Hence the marketers are advised to concentrate on the utilitarian motive of consumers along with product quality. The study also plants an important implication for the academicians as no prior study has tested the mediation effect of utilitarian motive in the relationship between product quality and consumer purchase intention. More glaring evidence could be gathered if researchers could conduct a similar kind of study in different contexts.

This study also could be utilized by marketers from different countries. India has been considered as a bright spot in terms of investment. At the same time, shopping malls are at the verge of expansion in India. Marketers from different parts of the world could take this opportunity and benefit from it. Therefore, we could conclude that this study leaves significant implications for marketers from India, marketers from abroad and most importantly to the academicians.

\section{LIMITATION OF THE STUDY}

Any study is not free from limitations. This research work also has some limitation in its basket. This study was conducted in the state of Chhattisgarh (Raipur, Bilaspur, and Durg). So, its implications could only generalize for the state of Chhattisgarh only or to the state which has a similar kind of characteristics. The study only talks about those consumers who were present in the shopping malls. The data were collected during three months. Hence any variations during that time were not exempted in this study.

\section{SCOPE OF THE STUDY}

India is a developing economy. The shopping mall culture is expanding at a very fast pace. Tier 2 and tier 3 cities are having large expansion in terms of shopping malls. This study was undertaken in the state of Chhattisgarh (Raipur, Bilaspur, and Durg). The data was collected from shopping malls, so the study could only be utilized in that context.

\section{CONCLUSION}

This study has empirically examined the relationship of various variables (product quality, product price, and utilitarian motive) with consumer purchase intention. The researcher has specifically focused on shopping malls. The researcher has used confirmatory factor analysis to check the reliability and validity of the constructs, and thereafter, the relationships between the variables were tested using structural equation modeling. To understand the mediation of utilitarian motive, the researcher has used structural modeling to check the mediation of utilitarian motive in the relationship of product quality and consumer purchase intention; product price and consumer purchase intention. All the independent variables were significantly and positively explaining the variation of consumer purchase intention. This research work concludes that all the relationship along with mediation analysis was found significant. Therefore, we could say that utilitarian motive does mediate the relationship of product quality and product price with consumer purchase intention.

\section{REFERENCES}

1. Babin, B. J., Darden, W. R., \& Griffin, M. (1994). Work and/or fun: measuring hedonic and utilitarian shopping value. Journal of consumer research, 20(4), 644-656.

2. Chi, H. K., Yeh, H. R., \& Huang, M. W. (2009). The Influences of advertising endorser, brand image, brand equity, price promotion on purchase intention: The mediating effect of advertising endorser. The Journal of Global Business Management, 5(1), 224-233.

3. Engardio, P., Roberts, D., \&Bremner, B. (2004). The China price. Business Week. New York,

4. Ghosh, A. (1990). Retail management. Chicago: Drydden press.

5. Jin, B., \& Kim, J. O. (2003). A typology of Korean discount shoppers: shopping motives, store attributes, and outcomes.International Journal of Service Industry Management. 14(4). 396-419. 
6. Keller,K. L. (2008). Strategic Brand Management. Building, Measuring, and Managing Brand Equity. 3 Ed., New Jersey. Pearson Education International.

7. Khraim, H. S. (2011). The Influence of Brand Loyalty on Cosmetics Buying Behavior of UAE Female Consumers.International Journal of Marketing Studies, 3(2), 123-133.

8. Kotler P. \& Armstrong, G. (2010). Principles of Marketing. New Jersey: Pearson Prentice Hall.

9. Lee, AbdouIllia, \&Assion Lawson- Body. (2010). Perceived price fairness of dynamic pricing. Journal of Industrial Management \& Data Systems, 111, 531- 550.

10. Sarwar, A. A. M., Azam, S. F., Haque, A. K. M., Sleman, G., \&Nikhashemi, S. R. (2013). Customer's perception towards buying Chinese products: An empirical investigation in Malaysia.World Applied Sciences Journal, 2(2), 152-160.

11. Shah, H., Aziz, A., Jaffari, A. R., Waris, S., Ejaz, W., Fatima, M., \&Sherazi., K. (2012). The Impact of Brands on Consumer Purchase Intentions. Asian Journal of Business Management, 4(2). 105-110.

12. Tsiotsou, R., (2006). The role of perceived product quality and overall satisfaction on purchase intention, International journal of consumer studies, 30(2), 207-217.

13. Yavas, U., \&Babakus, E. (2009). Modeling patronage behavior: Atri-partite conceptualization. Journal of Consumer Marketing, 26(7), 516-526.

14. Zeeshan, Z. (2013). The impact of mobile service attributes on males' and females' purchase decision.Management \& Marketing Challenges for the Knowledge Society, 8(4), 669-682.

15. Sivakoti Reddy, M. (2019). Impact of RSERVQUAL on customer satisfaction: A comparative analysis between traditional and multi-channel retailing. International Journal of Recent Technology and Engineering. 8(1), pp. 2917-2920.

16. Sivakoti Reddy, M., Venkateswarlu, N.(2019). Customer relationship management practices and their impact over customer purchase decisions: A study on the selected private sector banks housing finance schemes. International Journal of Innovative Technology and Exploring Engineering. 8(7), pp. 1720-1728.

17. Sivakoti Reddy, M., Murali Krishna, S.M.(2019). Influential role of retail service quality in food and grocery retailing: A comparative study between traditional and multi-channel retailing. International Journal of Management and Business Research. 9(2), pp. 68-73.

18. Sivakoti Reddy, M., Naga Bhaskar, M., Nagabhushan, A. (2016). Saga of silicon plate: An empirical analysis on the impact of socio economic factors of farmers on inception of solar plants. International Journal of Control Theory and Applications. 9(29), pp. 257-266.

19. Manukonda et al. (2019). What Motivates Students To Attend Guest Lectures?. The International Journal of Learning in Higher Education. Volume 26, Issue 1. 23-34.

20. Hymavathi, C.H., Koneru, K.(2019). Investors perception towards Indian commodity market: An empirical analysis with reference to Amaravathi region of Andhra Pradesh. International Journal of Innovative Technology and Exploring Engineering. 8(7), pp. 1708-1714.

21. Neelima, J., Koneru, K.(2019). Assessing the role of organizational culture in determining the employee performance - empirical evidence from Indian pharmaceutical sector. International Journal of Innovative Technology and Exploring Engineering. 8(7), pp. 1701-1707.

22. KishanVarma, M.S., Koneru, K., Yedukondalu, D.(2019). Affect of worksite wellness interventions towards occupational stress. International Journal of Recent Technology and Engineering. 8(1), pp. 2874-2879.

23. Hymavathi, C., Koneru, K. (2019). Role of perceived risk in mutual funds selection behavior: An analysis among the selected mutual fund investors. International Journal of Engineering and Advanced Technology. 8(4), pp. 1913-1920.

24. Suhasini, T., Koneru, K. (2019). Employee engagement through HRD practices on employee satisfaction and employee loyalty: An empirical evidence from Indian IT industry. International Journal of Engineering and Advanced Technology. 8(4), pp. 1788-1794.

25. Suhasini, T. Koneru, K. (2018). A study on employee engagement driving factors and their impact over employee satisfaction - An empirical evidence from Indian it industry. International Journal of Mechanical Engineering and Technology. 9(4), pp. 725-732.

26. Hymavathi, C.H., Koneru, K.(2018). Investors' awareness towards commodities market with reference to GUNTUR city, Andhra Pradesh. International Journal of Engineering and Technology(UAE). 7(2), pp 1104-1106. 